\title{
Effect of humidity on the production of ozone and other radicals by low-pressure mercury lamps
}

\author{
Ryo Ono ${ }^{\mathrm{a}, *}$, Yusuke Nakagawa ${ }^{\mathrm{b}}$, Yusuke Tokumitsu ${ }^{\mathrm{a}}$, Hiroyuki Matsumoto ${ }^{\mathrm{c}}$, \\ Tetsuji Oda ${ }^{\mathrm{b}}$ \\ ${ }^{a}$ Department of Advanced Energy, The University of Tokyo, 5-1-5 Kashiwanoha, \\ Kashiwa, Chiba 227-8568, Japan \\ ${ }^{b}$ Department of Electrical Engineering, The University of Tokyo, 7-3-1 Hongo, \\ Bunkyo-ku, Tokyo 113-8656, Japan \\ ${ }^{c}$ Corporate Advanced Technology Center, Iwasaki Electric Co., Ltd., 1-20 Fujimicho, \\ Gyoda, Saitama 361-0021, Japan
}

\begin{abstract}
An ultraviolet (UV) process using a low-pressure mercury lamp is affected by ambient humidity. It is due to strong influence of humidity on the production of ozone and other radicals by the UV light. In this paper, a photochemical reaction model under the irradiation of a low-pressure mercury lamp is developed, and the effect of humidity on the production of ozone and other radicals $\left[\mathrm{O}, \mathrm{O}\left({ }^{1} D\right), \mathrm{O}_{2}\left(a^{1} \Delta_{g}\right), \mathrm{O}_{2}\left(b^{1} \Sigma_{g}^{+}\right), \mathrm{OH}, \mathrm{HO}_{2}, \mathrm{H}\right.$, and $\mathrm{H}_{2} \mathrm{O}_{2}$ ] by a low-pressure mercury lamp is discussed using the reaction model. The validity of the reaction model is confirmed by comparing the ozone densities calculated using the model with experimentally measured ozone densities, and they showed good agreement. The reaction model shows that the ozone density decreases with increasing humidity for three reasons: (i) attenuation of $185 \mathrm{~nm}$ light due to absorption by $\mathrm{H}_{2} \mathrm{O}$, leading to a decreased $\mathrm{O}$ atom production by $\mathrm{O}_{2}+h \nu(185 \mathrm{~nm}) \rightarrow \mathrm{O}+\mathrm{O}$ which is required to produce ozone by $\mathrm{O}+\mathrm{O}_{2}+\mathrm{M} \rightarrow \mathrm{O}_{3}+\mathrm{M}$; (ii) ozone destruction by $\mathrm{O}_{3}+h \nu(254 \mathrm{~nm}) \rightarrow \mathrm{O}\left({ }^{1} D\right)+\mathrm{O}_{2}\left(a^{1} \Delta_{g}\right)$, where the resulting $\mathrm{O}\left({ }^{1} D\right)$ partly reacts with $\mathrm{H}_{2} \mathrm{O}$ before converting back to $\mathrm{O}_{3}$ after quenching to $\mathrm{O}$; and (iii) an ozone destruction cycle $\mathrm{OH}+\mathrm{O}_{3} \rightarrow \mathrm{HO}_{2}+\mathrm{O}_{2}$ and $\mathrm{HO}_{2}+\mathrm{O}_{3} \rightarrow \mathrm{OH}+2 \mathrm{O}_{2}$. The effect of humidity on the densities of other radicals is also discussed
\end{abstract}

*Corresponding author. Tel. and fax: +81 35841 6663; E-mail address: ryo-ono@k.utokyo.ac.jp.

Preprint submitted to J. Phtochem. Photobiol. A

September 16, 2013

(C) 2013. This manuscript version is made available under the Elsevier user license

http://www.elsevier.com/open-access/userlicense/1.0/ 
using the reaction model.

Keywords: low-pressure mercury lamp, humidity, ozone density, radicals, reaction model

\section{Introduction}

An ultraviolet (UV) process using a low-pressure mercury lamp is widely used for surface treatment, sterilization, and water treatment. The UV process often utilizes ozone produced by the UV light. In the "UV/O 3 process", it is empirically known that an increase in humidity reduces the ozone density, which can lower the effect of the $\mathrm{UV} / \mathrm{O}_{3}$ process. This is partially caused by the catalytic ozone destruction cycle involving $\mathrm{OH}$ and $\mathrm{HO}_{2}[1,2]$ :

$$
\begin{aligned}
\mathrm{OH}+\mathrm{O}_{3} & \rightarrow \mathrm{HO}_{2}+\mathrm{O}_{2}, \\
\mathrm{HO}_{2}+\mathrm{O}_{3} & \rightarrow \mathrm{OH}+2 \mathrm{O}_{2} .
\end{aligned}
$$

The production of $\mathrm{OH}$ and $\mathrm{HO}_{2}$ by a low-pressure mercury lamp was experimentally confirmed using light absorption measurements $[1,3]$.

In contrast, some UV processes are enhanced by humidification, such as those that use radicals produced in a humid environment (e.g., $\mathrm{OH}$ and $\mathrm{HO}_{2}$ ). The decomposition of volatile organic compounds (VOCs) using a low-pressure mercury lamp is enhanced by humidity because $\mathrm{OH}$ radicals efficiently decompose VOCs [4, 5]. Our group used a low-pressure mercury lamp for the surface treatment of dye-sensitized solar cells and found that the effect of using the lamp is improved by humidification [6]. Furthermore, some UV processes are not significantly influenced by humidity $[7,8]$. To understand the effects of humidity on the UV processes, the photochemical reactions occurring under the irradiation of a low-pressure mercury lamp should be investigated.

In this paper, a photochemical reaction model under the irradiation of a low-pressure mercury lamp is developed, and the effect of humidity on the densities of ozone and other radicals $\left[\mathrm{O}, \mathrm{O}\left({ }^{1} D\right), \mathrm{O}_{2}\left(a^{1} \Delta_{g}\right), \mathrm{O}_{2}\left(b^{1} \Sigma_{g}^{+}\right), \mathrm{OH}\right.$, $\mathrm{HO}_{2}, \mathrm{H}$, and $\mathrm{H}_{2} \mathrm{O}_{2}$ ] produced by the lamp is examined using the reaction model. After the reaction model is described in the next section, the validity of the reaction model is confirmed by comparing the ozone densities calculated using the model with experimentally measured ozone densities. Then, the effect of humidity on the production of ozone and other radicals is dis- 
cussed using the reaction model. Particularly, the decrease in ozone density with increasing humidity is discussed in detail.

\section{Reaction model}

The reaction model under the irradiation of a low-pressure mercury lamp is described in this section. The low-pressure mercury lamp emits radiation

at wavelengths of $185 \mathrm{~nm}$ and $254 \mathrm{~nm}$. The $185 \mathrm{~nm}$ radiation dissociates $\mathrm{O}_{2}$ into $\mathrm{O}\left({ }^{3} P\right)$ :

$$
\mathrm{O}_{2}+h \nu(185 \mathrm{~nm}) \rightarrow \mathrm{O}\left({ }^{3} \mathrm{P}\right)+\mathrm{O}\left({ }^{3} P\right) .
$$

$\mathrm{O}\left({ }^{3} \mathrm{P}\right)$ reacts with $\mathrm{O}_{2}$ to produce $\mathrm{O}_{3}$ :

$$
\mathrm{O}\left({ }^{3} P\right)+\mathrm{O}_{2}+\mathrm{M} \rightarrow \mathrm{O}_{3}+\mathrm{M}
$$

$\mathrm{O}_{3}$ is dissociated by the $254 \mathrm{~nm}$ radiation to produce $\mathrm{O}\left({ }^{1} D\right), \mathrm{O}\left({ }^{3} P\right), \mathrm{O}_{2}\left(a^{1} \Delta_{g}\right)$, and $\mathrm{O}_{2}(v)$ :

$$
\begin{aligned}
\mathrm{O}_{3}+h \nu(254 \mathrm{~nm}) \stackrel{\stackrel{\phi_{3}}{\longrightarrow}}{\longrightarrow} \mathrm{O}\left({ }^{1} D\right)+\mathrm{O}_{2}\left(a^{1} \Delta_{g}\right), \\
\stackrel{1-\phi_{3}}{\longrightarrow} \mathrm{O}\left({ }^{3} P\right)+\mathrm{O}_{2}\left(X^{3} \Sigma_{g}^{-}, v\right),
\end{aligned}
$$

where $\phi_{3}=0.9[9]$.

In addition, the $185 \mathrm{~nm}$ radiation dissociates $\mathrm{H}_{2} \mathrm{O}$ :

$$
\mathrm{H}_{2} \mathrm{O}+h \nu(185 \mathrm{~nm}) \rightarrow \mathrm{H}+\mathrm{OH} .
$$

Thus, the UV radiation from the low-pressure mercury lamp produces $\mathrm{O}\left({ }^{3} P\right)$, $\mathrm{O}\left({ }^{1} D\right), \mathrm{O}_{2}(a), \mathrm{O}_{3}, \mathrm{OH}$, and $\mathrm{H}$. These radicals react as shown in reactions $\mathrm{R} 5$ R32, which are listed in Table 1 along with their rate coefficients at $298 \mathrm{~K}$. The absorption cross-sections and the rate coefficients of reactions R1-R4 are also shown in Table 1.

The cross-section of R1, $\sigma_{1}$, is uncertain. It was previously reported that $\sigma_{1}$ of the low-pressure mercury lamp depends on the $\mathrm{O}_{2}$ column, with values ranging from $0.6 \times 10^{-20}$ to $1.2 \times 10^{-20} \mathrm{~cm}^{2}$ [16]. In another study [17], the range of values for $\sigma_{1}$ were reported to be $1.4 \times 10^{-20}$ to $1.8 \times 10^{-20} \mathrm{~cm}^{2}$. In our experiment, $\sigma_{1}$ is measured using our lamp, as shown in the next section, and is estimated to be $1.2 \times 10^{-20} \mathrm{~cm}^{2}$. This $\sigma_{1}$ value is used in our model. 
Table 1: Rate coefficients $\left(k\left[\mathrm{~cm}^{3} / \mathrm{s}\right]\right)$ at $298 \mathrm{~K}$ and cross-sections $\left(\sigma\left[\mathrm{cm}^{2}\right]\right)$ of the reactions considered in the reaction model. The ratios written in R7, R10, R13-R16, and R22 are branching ratios.

\begin{tabular}{|c|c|c|c|}
\hline & Reactions & $k$ and $\sigma$ & Refs. \\
\hline$(\mathrm{R} 1)$ & $\mathrm{O}_{2}+h \nu(185 \mathrm{~nm}) \rightarrow \mathrm{O}+\mathrm{O}$ & a) $\sigma_{1}=1.5 \times 10^{-20}$ & - \\
\hline$(\mathrm{R} 2)$ & $\mathrm{O}+\mathrm{O}_{2}+\mathrm{M} \rightarrow \mathrm{O}_{3}+\mathrm{M}$ & $\begin{aligned} k_{2} & =6.0 \times 10^{-34}\left[\mathrm{O}_{2}\right] \\
& =5.6 \times 10^{-34}\left[\mathrm{~N}_{2}\right]\end{aligned}$ & [10] \\
\hline (R3) & $\mathrm{O}_{3}+h \nu(254 \mathrm{~nm}) \rightarrow$ products & $\sigma_{3}=1.16 \times 10^{-17}$ & [11] \\
\hline (R4) & $\mathrm{H}_{2} \mathrm{O}+h \nu(185 \mathrm{~nm}) \rightarrow \mathrm{H}+\mathrm{OH}$ & $\sigma_{4}=7.14 \times 10^{-20}$ & [10] \\
\hline (R5) & $\mathrm{O}+\mathrm{O}_{3} \rightarrow \mathrm{O}_{2}+\mathrm{O}_{2}$ & $k_{5}=8.0 \times 10^{-15}$ & {$[10]$} \\
\hline (R6) & $\mathrm{O}\left({ }^{1} D\right)+\mathrm{N}_{2} \rightarrow \mathrm{O}+\mathrm{N}_{2}$ & $k_{6}=2.6 \times 10^{-11}$ & [12] \\
\hline (R7) & $\mathrm{O}\left({ }^{1} D\right)+\mathrm{O}_{2} \rightarrow \mathrm{O}+\mathrm{O}_{2}(X, a, b)$ & $k_{7}=4.0 \times 10^{-11} \quad(15: 5: 80)$ & [10] \\
\hline (R8) & $\mathrm{O}\left({ }^{1} D\right)+\mathrm{H}_{2} \mathrm{O} \rightarrow \mathrm{OH}+\mathrm{OH}$ & $k_{8}=2.2 \times 10^{-10}$ & [10] \\
\hline (R9) & $\mathrm{O}\left({ }^{1} D\right)+\mathrm{O}_{3} \rightarrow \mathrm{O}_{2}+\mathrm{O}_{2}, \mathrm{O}_{2}+\mathrm{O}+\mathrm{O}$ & $k_{9}=2.4 \times 10^{-10} \quad(1: 1)$ & [10] \\
\hline (R10) & $\mathrm{O}_{2}(a)+\mathrm{O}_{2} \rightarrow \mathrm{O}_{2}+\mathrm{O}_{2}$ & $k_{10}=1.6 \times 10^{-18}$ & [10] \\
\hline (R11) & $\mathrm{O}_{2}(a)+\mathrm{O}_{3} \rightarrow \mathrm{O}_{2}+\mathrm{O}_{2}+\mathrm{O}$ & $k_{11}=3.8 \times 10^{-15}$ & [10] \\
\hline (R12) & $\mathrm{O}_{2}(a)+\mathrm{H}_{2} \mathrm{O} \rightarrow \mathrm{O}_{2}+\mathrm{H}_{2} \mathrm{O}$ & $k_{12}=5 \times 10^{-18}$ & [10] \\
\hline (R13) & $\mathrm{O}_{2}(a)+\mathrm{O}_{2}(a) \rightarrow \mathrm{O}_{2}(X, b)+\mathrm{O}_{2}$ & $k_{13}=2.8 \times 10^{-17}(1: 1)$ & [13] \\
\hline (R14) & $\mathrm{O}_{2}(b)+\mathrm{N}_{2} \rightarrow \mathrm{O}_{2}(X, a)+\mathrm{O}_{2}$ & $k_{14}=2.1 \times 10^{-15} \quad(1: 9)$ & {$[10,13]$} \\
\hline (R15) & $\mathrm{O}_{2}(b)+\mathrm{H}_{2} \mathrm{O} \rightarrow \mathrm{O}_{2}(X, a)+\mathrm{H}_{2} \mathrm{O}$ & $k_{15}=4.6 \times 10^{-12}(1: 9)$ & {$[10,13]$} \\
\hline (R16) & $\mathrm{O}_{2}(b)+\mathrm{O}_{3} \rightarrow \mathrm{O}_{2}(X, a)+\mathrm{O}_{3}, \mathrm{O}+2 \mathrm{O}_{2}$ & $k_{16}=2.2 \times 10^{-11} \quad(3: 27: 70)$ & {$[10,13]$} \\
\hline (R17) & $\mathrm{OH}+\mathrm{O} \rightarrow \mathrm{O}_{2}+\mathrm{H}$ & $k_{17}=3.5 \times 10^{-11}$ & [10] \\
\hline (R18) & $\mathrm{H}+\mathrm{O}_{2}+\mathrm{M} \rightarrow \mathrm{HO}_{2}+\mathrm{M}$ & $k_{18}=5.5 \times 10^{-32}\left[\mathrm{~N}_{2}\right]$ & [10] \\
\hline (R19) & $\mathrm{HO}_{2}+\mathrm{O} \rightarrow \mathrm{OH}+\mathrm{O}_{2}$ & $k_{19}=5.8 \times 10^{-11}$ & {$[10]$} \\
\hline (R20) & $\mathrm{OH}+\mathrm{HO}_{2} \rightarrow \mathrm{H}_{2} \mathrm{O}+\mathrm{O}_{2}$ & $k_{20}=1.1 \times 10^{-10}$ & [10] \\
\hline (R21) & $\mathrm{H}+\mathrm{O}_{3} \rightarrow \mathrm{OH}+\mathrm{O}_{2}$ & $k_{21}=2.9 \times 10^{-11}$ & [14] \\
\hline (R22) & $\mathrm{H}+\mathrm{HO}_{2} \rightarrow \mathrm{OH}+\mathrm{OH}, \mathrm{H}_{2}+\mathrm{O}_{2}, \mathrm{H}_{2} \mathrm{O}+\mathrm{O}$ & $k_{22}=8.0 \times 10^{-11} \quad(90: 7: 3)$ & [10] \\
\hline (R23) & $\mathrm{H}+\mathrm{OH}+\mathrm{M} \rightarrow \mathrm{H}_{2} \mathrm{O}+\mathrm{M}$ & $\begin{aligned} k_{23} & =6.9 \times 10^{-31}\left[\mathrm{~N}_{2}\right] \\
& =4.4 \times 10^{-30}\left[\mathrm{H}_{2} \mathrm{O}\right]\end{aligned}$ & [15] \\
\hline (R24) & $\mathrm{OH}+\mathrm{OH} \rightarrow \mathrm{H}_{2} \mathrm{O}+\mathrm{O}$ & $k_{24}=1.5 \times 10^{-12}$ & [10] \\
\hline (R25) & $\mathrm{OH}+\mathrm{OH}+\mathrm{M} \rightarrow \mathrm{H}_{2} \mathrm{O}_{2}+\mathrm{M}$ & b) $k_{25}=5.2 \times 10^{-12}$ & [10] \\
\hline (R26) & $\mathrm{OH}+\mathrm{H}_{2} \mathrm{O}_{2} \rightarrow \mathrm{H}_{2} \mathrm{O}+\mathrm{HO}_{2}$ & $k_{26}=1.7 \times 10^{-12}$ & [10] \\
\hline (R27) & $\mathrm{OH}+\mathrm{O}_{3} \rightarrow \mathrm{HO}_{2}+\mathrm{O}_{2}$ & $k_{27}=7.3 \times 10^{-14}$ & [10] \\
\hline (R28) & $\mathrm{HO}_{2}+\mathrm{HO}_{2}+\mathrm{M} \rightarrow \mathrm{H}_{2} \mathrm{O}_{2}+\mathrm{O}_{2}+\mathrm{M}$ & b,c) $k_{28}^{0}=2.9 \times 10^{-12}$ & [10] \\
\hline (R29) & $\mathrm{HO}_{2}+\mathrm{O}_{3} \rightarrow \mathrm{OH}+2 \mathrm{O}_{2}$ & $k_{29}=2.0 \times 10^{-15}$ & [10] \\
\hline (R30) & $\mathrm{O}+\mathrm{H}_{2} \mathrm{O}_{2} \rightarrow \mathrm{OH}+\mathrm{HO}_{2}$ & $k_{30}=1.7 \times 10^{-15}$ & [10] \\
\hline (R31) & $\mathrm{H}_{2} \mathrm{O}_{2}+h \nu(185 \mathrm{~nm}) \rightarrow \mathrm{OH}+\mathrm{OH}$ & $\sigma_{31}=8 \times 10^{-19}$ & [10] \\
\hline (R32) & $\mathrm{H}_{2} \mathrm{O}_{2}+h \nu(254 \mathrm{~nm}) \rightarrow \mathrm{OH}+\mathrm{OH}$ & $\sigma_{32}=7.0 \times 10^{-20}$ & [10] \\
\hline
\end{tabular}

a) See text.

b) Calculated using low- and high-pressure limits and broadening factor.

c) $k_{28}=k_{28}^{0}\left\{1+1.4 \times 10^{-21} \exp (2200 / T)\left[\mathrm{H}_{2} \mathrm{O}\right]\right\}$ 


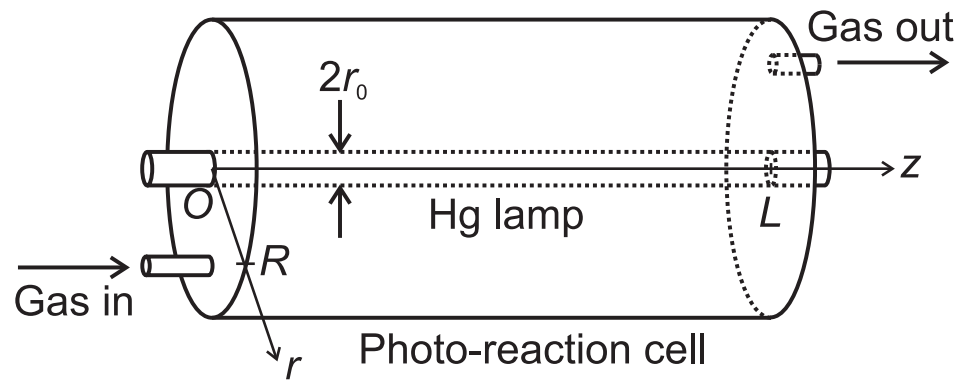

Figure 1: Photo-reaction cell equipped with a low-pressure mercury lamp.

\section{Verification of reaction model}

For the verification of the reaction model developed in the previous section, the ozone densities calculated using the reaction model are compared with experimentally measured ozone densities. A cylindrical reaction cell equipped with a low-pressure mercury lamp shown in Fig. 1 is used for the verification. The ozone density at the gas outlet of the reaction cell is measured and compared with that calculated using the reaction model. The experiment and simulation are detailed below.

\subsection{Experiment}

A 36-cm long low-pressure mercury lamp is placed in the cylindrical cell, as shown in Fig. 1. The photo-reaction cell is made from aluminum, and black non-glossy paint is applied to the inner wall of the cell to reduce reflections. The radius of the lamp, $r_{0}$, is $0.9 \mathrm{~cm}$ and the length of the cell, $L$, is $30 \mathrm{~cm}$. The UV lamp emits radiation continuously. Humid air or humid $\mathrm{O}_{2}(50 \%) / \mathrm{N}_{2}$ is allowed to flow through the reaction cell. Two conditions of $\mathrm{O}_{2}=20 \%$ and $50 \%$ are used to verify the reaction model for different $\mathrm{O}_{2}$ concentrations. Temperature and humidity are measured at the gas outlet. After the lamp is switched on, the ozone density increases with time and reaches equilibrium after around $20 \mathrm{~min}$. After equilibrium conditions are reached, the ozone density at the gas outlet is measured using an UV absorption method. A 2-cm quartz absorption cell and 254-nm radiation from another low-pressure mercury lamp are used for the UV absorption. The 254-nm light is absorbed by $\mathrm{H}_{2} \mathrm{O}_{2}$ as well as ozone (see R32). However, the ozone density measurement is not disturbed by $\mathrm{H}_{2} \mathrm{O}_{2}$ because the absorption cross section of ozone at $254 \mathrm{~nm}$ is two orders of magnitude larger than that of $\mathrm{H}_{2} \mathrm{O}_{2}$ (Table 1) and 
the density of ozone is orders of magnitude higher than that of $\mathrm{H}_{2} \mathrm{O}_{2}$ (see Fig. 4). To verify the reaction model for different conditions, the gas flow rate is changed between 1.5 and $12 \mathrm{~L} / \mathrm{min}$ and two sizes of photo-reaction cells are used: $R=4 \mathrm{~cm}$ and $8 \mathrm{~cm}$ where $R$ is the inner radius of the cell. The gas flow rates and the cell sizes are chosen to fix the ozone density into a range of about $2.5 \times 10^{15}$ to $2.5 \times 10^{16} \mathrm{~cm}^{-3}(100$ to $1000 \mathrm{ppm})$, which is typical values for actual $\mathrm{UV} / \mathrm{O}_{3}$ processes.

The radiation power of the lamp is measured as follows. The lamp is placed outside the photo-reaction cell, and the illuminance of $185 \mathrm{~nm}$ and $254 \mathrm{~nm}$ radiation is measured at different distances from the lamp surface at the midst of the lamp. The $185 \mathrm{~nm}$ and $254 \mathrm{~nm}$ light is measured using the illuminometers H9535-172 (Hamamatsu) and UV-M02 (Orc), respectively. H9535-172 is calibrated for $172 \mathrm{~nm}$ light but is also sensitive to $185 \mathrm{~nm}$. A spectral response provided on its manual is used for calibration. Then, the illuminance is numerically simulated, and the radiation power is determined by fitting the simulated values to the measured results. In the simulation of the illuminance, the photon flux at the measurement point is volume integrated over the lamp volume. The $\cos \theta$ dependence of the 254 -nm illuminometer is not good, and the details of this dependency provided by the manufacturer is considered in the simulation. The radiation power is determined to be $1.9 \mathrm{~W}$ for $185 \mathrm{~nm}$ and $12.2 \mathrm{~W}$ for $254 \mathrm{~nm}$.

In addition, the cross section of R1, $\sigma_{1}$, is determined by the fitting of measured and simulated 185-nm illuminance. It is determined to be $1.2 \times$ $10^{-20} \mathrm{~cm}^{2}$. In the calculation of $\sigma_{1}$, the absorption of $185 \mathrm{~nm}$ by $\mathrm{H}_{2} \mathrm{O}$ (see R4) in the presence of humidity, where the 185-nm illuminance was measured, is also considered.

\subsection{Simulation}

The radical densities in the photo-reaction cell are simulated using the reaction model. The aim of the simulation is to verify the reaction model and not to develop an exhaustive simulation. Therefore, assumptions are made to simplify the modeling.

The cylindrical axis $(r, z)$ shown in Fig. 1 is used in the simulation. The inside of the photo-reaction cell is divided into uniform computational mesh. The densities of short-lived radicals $\left[\mathrm{O}, \mathrm{O}\left({ }^{1} D\right), \mathrm{O}_{2}(a), \mathrm{O}_{2}(b), \mathrm{OH}, \mathrm{HO}_{2}\right.$, and $\mathrm{H}]$ at a point $(r, z)$ are calculated by solving the rate equations obtained from Table 1 under equilibrium conditions (e.g., $\left.d[\mathrm{O}]_{r, z} / d t=0\right)$. Diffusion is neglected for those radicals. The numbers of the mesh are sufficiently large: 
100 for $r$-direction and 300 for $z$-direction, respectively. It was confirmed that the calculated radical densities are not affected by the number of the mesh for larger than $100 \times 300$ meshes. The photon flux at $185 \mathrm{~nm}$ and $254 \mathrm{~nm}$ at a point $(r, z)$ is calculated by integrating the photon flux over the lamp volume. The light absorption due to reactions R1, R3, and R4 is considered in the calculation of the photon flux.

For long-lived species $\left(\mathrm{O}_{3}\right.$ and $\left.\mathrm{H}_{2} \mathrm{O}_{2}\right)$, two models are assumed. In "model 1 ", it is assumed that $\mathrm{O}_{3}$ and $\mathrm{H}_{2} \mathrm{O}_{2}$ diffuse sufficiently and that their densities are uniform in the photo-reaction cell. Under equilibrium conditions, the number of ozone molecules in the reaction cell does not change with time. The number of ozone molecules flowing out from the reaction cell per unit time is $F\left[\mathrm{O}_{3}\right]_{0}$, where $F$ is the volumetric flow rate of the gas and $\left[\mathrm{O}_{3}\right]_{0}$ is the ozone density in the reaction cell which is uniform in the cell. Under equilibrium conditions, the value of $F\left[\mathrm{O}_{3}\right]_{0}$ is equal to the number of ozone molecules produced in the reaction cell per unit time:

$$
F\left[\mathrm{O}_{3}\right]_{0}=\int_{V}\left(\frac{d\left[\mathrm{O}_{3}\right]}{d t}\right)_{r, z} d V
$$

where $\left(d\left[\mathrm{O}_{3}\right] / d t\right)_{r, z}$ is increase in ozone density at $(r, z)$ by reactions $\mathrm{R} 1-$ R32 per unit time and the integral is volume integration in the reaction cell. The $\mathrm{O}_{3}$ density is calculated by solving Eq. (1). The $\mathrm{H}_{2} \mathrm{O}_{2}$ density is also calculated using the same way.

In model 1, it was assumed that the $\mathrm{O}_{3}$ and $\mathrm{H}_{2} \mathrm{O}_{2}$ densities are uniform in the photo-reaction cell. However, their densities must be slightly or much lower at the upstream side (near the inlet of the photo-reaction cell) and higher at the downstream side (near the outlet) because they are accumulated as the gas flows downstream. Accurate calculation of their density distribution requires fluid dynamics model, which is beyond the scope of the present work. Instead, in "model 2", it is simply assumed that their densities have gradients in the $z$-direction and uniform in the $r$-direction with boundary conditions of $\left[\mathrm{O}_{3}\right]=0$ and $\left[\mathrm{H}_{2} \mathrm{O}_{2}\right]=0$ at the inlet of the reaction cell $(z=0)$. The ozone density at $z,\left[\mathrm{O}_{3}\right]_{z}$, is calculated as follows. In an infinitely short time of $\Delta t$, the gas flows by $\Delta z=v_{z} \Delta t$, where $v_{z}$ is the average flow velocity of the gas, and the ozone density increases by $\left(d\left[\mathrm{O}_{3}\right]_{z} / d z\right) \Delta z$. At the same time, the increase in ozone density in $\Delta t$ by reactions $\mathrm{R} 1-\mathrm{R} 32$ at $(r, z)$ can also be written as $\left(d\left[\mathrm{O}_{3}\right] / d t\right)_{r, z} \Delta t$. Therefore, the following 
equation holds:

$$
\begin{aligned}
\int_{S} \frac{d\left[\mathrm{O}_{3}\right]_{z}}{d z} \Delta z d S & =\int_{S}\left(\frac{d\left[\mathrm{O}_{3}\right]}{d t}\right)_{r, z} \Delta t d S, \\
\therefore v_{z} \frac{d\left[\mathrm{O}_{3}\right]_{z}}{d z} \int_{S} d S & =\int_{S}\left(\frac{d\left[\mathrm{O}_{3}\right]}{d t}\right)_{r, z} d S
\end{aligned}
$$

where the integral, $\int_{S} d S=\int_{r_{0}}^{R} 2 \pi r d r$, is surface integral at $z$. The ozone density is calculated by solving Eq. (2). The $\mathrm{H}_{2} \mathrm{O}_{2}$ density is also calculated using the same way.

\section{Results and discussion}

\subsection{Comparison between simulation and experiment}

Figure 2 compares the simulated and measured ozone densities under different flow and humidity conditions. In Fig. $2(\mathrm{e}), \mathrm{O}_{2}(50 \%) / \mathrm{N}_{2}$ gas is used instead of air. The $\mathrm{O}_{3}$ and $\mathrm{H}_{2} \mathrm{O}_{2}$ densities are calculated using both models 1 and 2 , and their results are shown. Figure 2 shows that the simulation underestimates the ozone density by $30-70 \%$ than the measured values for all conditions, but it simulates well the effect of humidity on ozone density. Considering that the rate coefficients listed in Table 1 have generally an uncertainty of 10\%-30\% [10] and some simplifying assumptions are made in the simulation, the errors of $30-70 \%$ are allowable. Thus, it can be concluded that the reaction model is suitable.

The reaction model has been verified. Next, the decrease in ozone density with increasing humidity is discussed using the reaction model. Then, the effect of humidity on the densities of other radicals is examined using the reaction model. These information is important for an efficient use of the UV process with a low-pressure mercury lamp in a humid environment.

\subsection{Reduction of $\mathrm{O}_{3}$ density with increasing humidity}

Figure 2 shows that the ozone density is reduced with increasing humidity. There are three reasons for this reduction.

1. Absorption of $185 \mathrm{~nm}$ radiation by $\mathrm{H}_{2} \mathrm{O}$ : (R4).

2. Consumption of $\mathrm{O}\left({ }^{1} D\right)$ by $\mathrm{H}_{2} \mathrm{O}$ : (R8).

3. Catalytic ozone destruction by $\mathrm{OH}$ and $\mathrm{HO}_{2}$ : (R27) and (R29). 

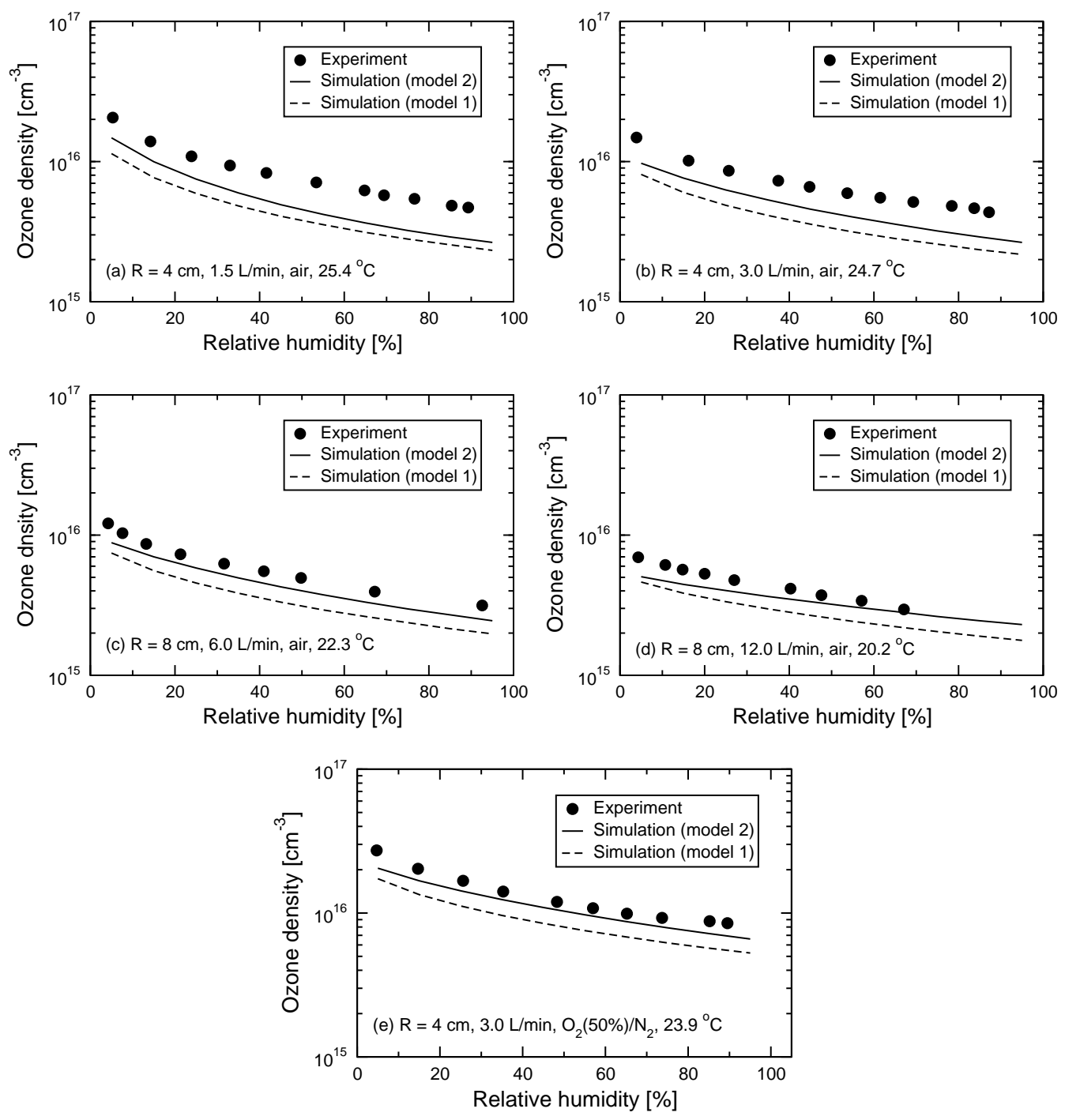

Figure 2: Comparison of the ozone densities obtained from simulation and experiments under different humidity, $\mathrm{O}_{2}$ concenration, and flow conditions. 


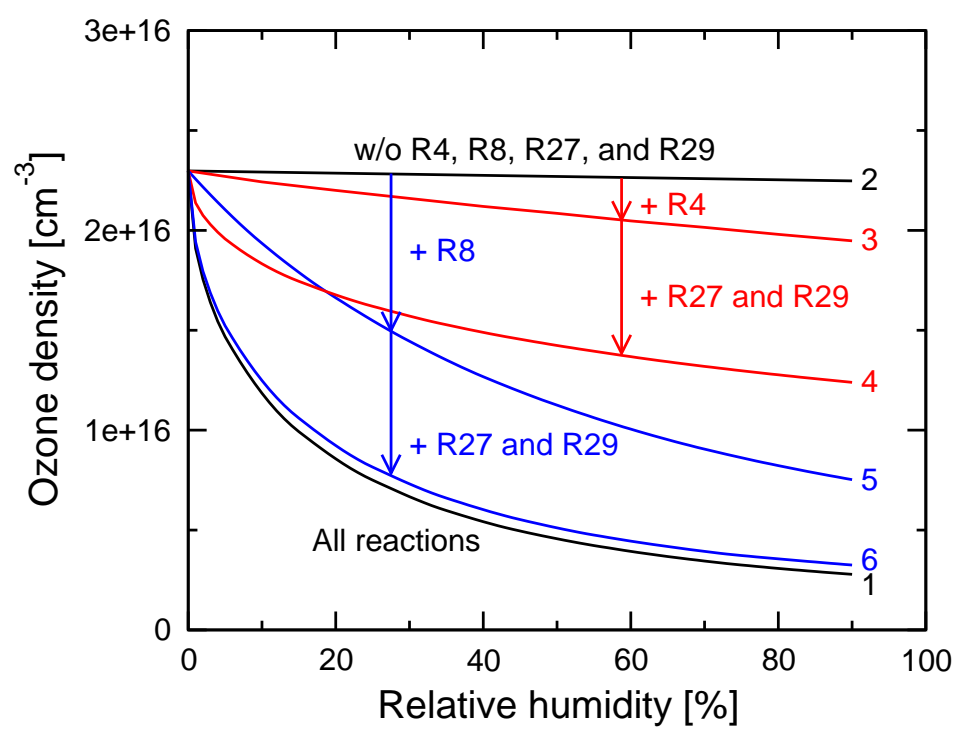

Figure 3: Simulation of ozone density versus relative humidity using model 2. Curve 1 is calculated using all reactions R1-R32. Curves $2-6$ are calculated by excluding some reactions. Here $R=4 \mathrm{~cm}, T=25{ }^{\circ} \mathrm{C}$, and $1.5 \mathrm{~L} / \mathrm{min}$.

Curve 1 in Fig. 3 shows a simulated ozone density calculated using all reactions R1-R32 and curve 2 is calculated excluding the following reactions: R4, $\mathrm{R} 8, \mathrm{R} 27$, and R29. It can be observed that curve 2 is almost independent of humidity, indicating that the ozone reduction by humidity is in fact caused by these three processes. These processes are discussed below in detail.

\subsubsection{Absorption of $185 \mathrm{~nm}$ radiation by $\mathrm{H}_{2} \mathrm{O}$}

The $185 \mathrm{~nm}$ radiation from the lamp is absorbed by $\mathrm{O}_{2}$ and $\mathrm{H}_{2} \mathrm{O}$ according to $\mathrm{R} 1$ and $\mathrm{R} 4$. The ratio of the absorption by $\mathrm{O}_{2}$ is $\sigma_{1}\left[\mathrm{O}_{2}\right] /\left(\sigma_{1}\left[\mathrm{O}_{2}\right]+\sigma_{4}\left[\mathrm{H}_{2} \mathrm{O}\right]\right)$, which decreases with increasing humidity. As a result, the production of $\mathrm{O}\left({ }^{3} P\right)$ by $\mathrm{R} 1$ is reduced with increasing humidity, leading to decreased ozone production by R2. Curve 3 in Fig. 3 is a simulation where R4 is added to the conditions of curve 2. The difference between curves 2 and 3 indicates the ozone reduction caused by the absorption of $185 \mathrm{~nm}$ light by $\mathrm{H}_{2} \mathrm{O}(\mathrm{R} 4)$.

\subsubsection{Consumption of $\mathrm{O}\left({ }^{1} \mathrm{D}\right)$ by $\mathrm{H}_{2} \mathrm{O}$}

Ozone is photodissociated by $\mathrm{R} 3$ to produce $\mathrm{O}\left({ }^{3} P\right)$ and $\mathrm{O}\left({ }^{1} D\right)$. $\mathrm{O}\left({ }^{3} P\right)$ converts back to $\mathrm{O}_{3}$ by $\mathrm{R} 2$, and $\mathrm{O}\left({ }^{1} D\right)$ also reacts to form $\mathrm{O}_{3}$ by $\mathrm{R} 2$ after 
quenching to $\mathrm{O}\left({ }^{3} P\right)$ by $\mathrm{N}_{2}$ and $\mathrm{O}_{2}$ as $\mathrm{R} 6$ and R7. Because of this regeneration cycle, ozone is not practically decomposed by R3. However, in humid conditions, a part of $\mathrm{O}\left({ }^{1} D\right)$ reacts with $\mathrm{H}_{2} \mathrm{O}(\mathrm{R} 8)$ and does not get converted back to ozone. Because of this branching from the ozone regeneration cycle, ozone is partly decomposed by R3. Curve 5 in Fig. 3 is a simulation obtained by adding $\mathrm{R} 8$ to the conditions of curve 2 . The difference between curves 2 and 5 indicates the ozone reduction caused by R 8 that breaks the ozone regeneration cycle.

\subsubsection{Catalytic ozone destruction by $\mathrm{OH}$ and $\mathrm{HO}_{2}$}

In humid conditions, ozone is decomposed by the ozone destruction cycle involving $\mathrm{OH}$ and $\mathrm{HO}_{2}$, as shown in R27 and R29. Curves 4 and 6 in Fig. 3 are the simulations where the ozone destruction cycle, R27 and R29, have been added to the conditions of curves 3 and 5 , respectively. In both cases, the ozone density is remarkably reduced by the ozone destruction cycle.

\subsection{Other radical densities}

The effect of humidity on the densities of other radicals is examined. The radical densities are calculated in the reaction cell of $R=4 \mathrm{~cm}$ with $T=25^{\circ} \mathrm{C}$ and $F=1.5 \mathrm{~L} / \mathrm{min}$ conditions as an example. Figure 4 shows the calculated densities under different humidity conditions near the inner wall of the photo-reaction cell $(r=R)$ and near the lamp surface $\left(r=r_{0}\right)$ at the center cross-section of the photo-reaction cell $(z=L / 2)$. The densities of $\mathrm{O}\left({ }^{1} D\right), \mathrm{O}_{2}(b)$, and $\mathrm{H}$ are not plotted in Fig. 4 because they are too small of the orders of $10^{5} \sim 10^{6} \mathrm{~cm}^{-3}, 10^{6} \sim 10^{7} \mathrm{~cm}^{-3}$, and $10^{7} \sim 10^{9} \mathrm{~cm}^{-3}$, respectively. Near the inner wall of the reaction cell $(r=R)$, the densities of $\mathrm{O}_{3}, \mathrm{O}_{2}(a), \mathrm{H}_{2} \mathrm{O}_{2}, \mathrm{HO}_{2}, \mathrm{OH}$, and $\mathrm{O}$ are of the orders of $10^{15} \mathrm{~cm}^{-3}, 10^{13} \mathrm{~cm}^{-3}$, $10^{13} \mathrm{~cm}^{-3}, 10^{12} \mathrm{~cm}^{-3}, 10^{11} \mathrm{~cm}^{-3}$, and $10^{10} \mathrm{~cm}^{-3}$, respectively. Near the lamp surface $\left(r=r_{0}\right)$, the radical densities increase because the photon flux from the lamp is larger than that at $r=R$.

Figure 4 shows radical densities and effect of humidity for typical conditions for actual $\mathrm{UV} / \mathrm{O}_{3}$ process: several $\mathrm{cm}$ distance from the lamp surface with $\mathrm{O}_{3}$ density of the order of $10^{15} \mathrm{~cm}^{-3}$. It shows that ozone has the highest density among the radicals. The density of atomic oxygen is 4 to 5 orders of magnitude lower than the ozone density, but its dependence on humidity is approximately the same as the ozone density. Radicals originating from water vapor, $\mathrm{OH}, \mathrm{HO}_{2}$, and $\mathrm{H}_{2} \mathrm{O}_{2}$, are produced in humid environment. But their densities do not necessarily increase with humidity. The densities of 

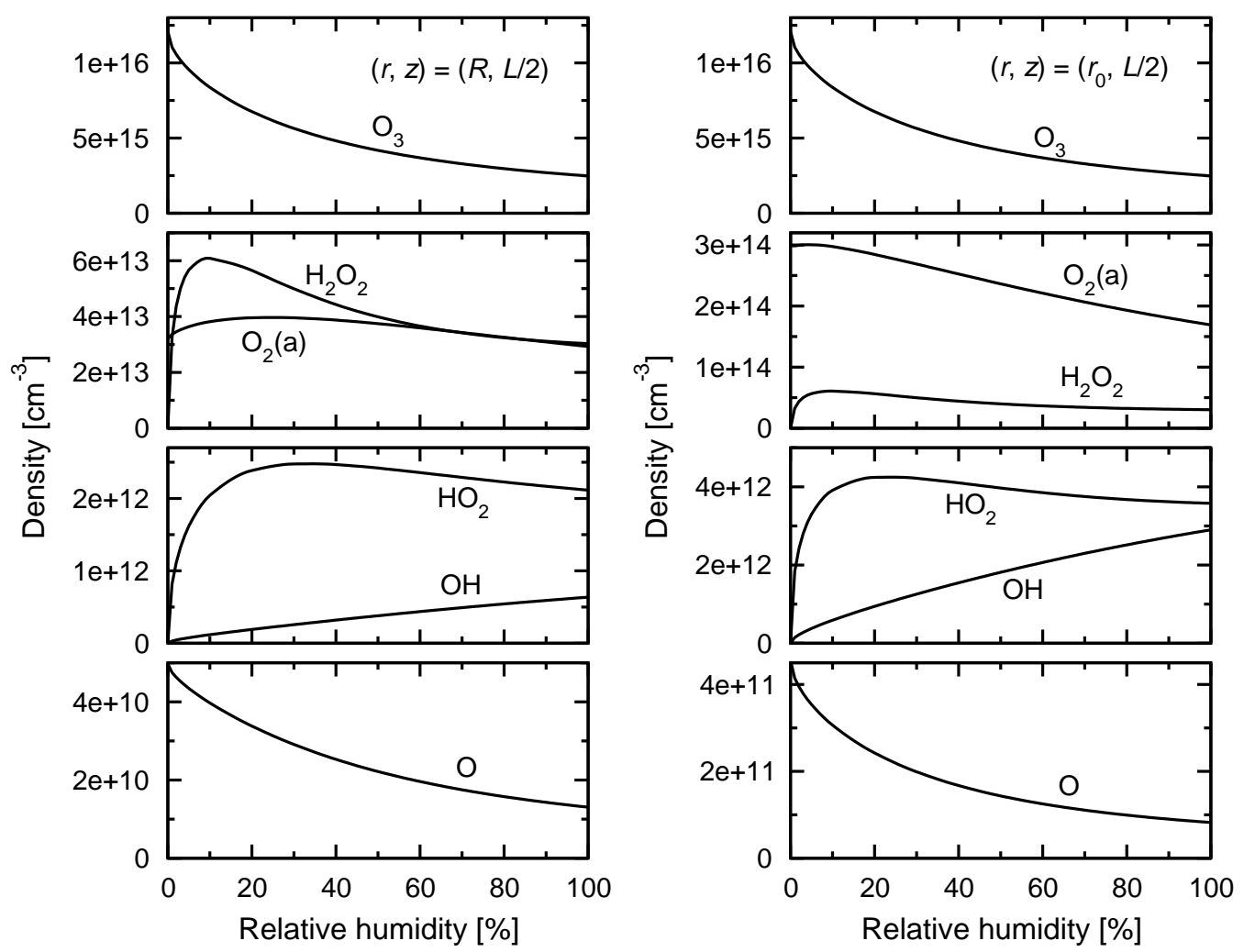

Figure 4: Simulation of the radical densities for different humidity conditions at $(r, z)=$ $(R, L / 2)$ and $\left(r_{0}, L / 2\right)$. They are calculated using model 2 . Here $R=4 \mathrm{~cm}, T=25^{\circ} \mathrm{C}$, and $F=1.5 \mathrm{~L} / \mathrm{min}$.

$\mathrm{HO}_{2}$ and $\mathrm{H}_{2} \mathrm{O}_{2}$ reach maxima at relative humidity of 5-20\%. Further increase in humidity decreases their densities. On the other hand, the $\mathrm{OH}$ density increases in nearly proportional to humidity. The density of $\mathrm{O}_{2}(a)$ is almost independent of humidity at $r=R$, while decreases with increasing humidity at $r=r_{0}$.

The densities of radicals and their dependence on humidity can be obtained from Fig. 4, but only for the limited condition. Next, a simple model is deduced to estimate those radical densities for more general conditions. If the ozone density and illuminance of $185 \mathrm{~nm}$ and $254 \mathrm{~nm}$ light are known, approximate radical densities can be analytically estimated. For example, 
the density of $\mathrm{O}\left({ }^{1} D\right)$ can be approximated by

$$
\left[\mathrm{O}\left({ }^{1} D\right)\right] \cong \frac{\phi_{3} \sigma_{3} I_{254}\left[\mathrm{O}_{3}\right]}{k_{6}\left[\mathrm{~N}_{2}\right]+k_{7}\left[\mathrm{O}_{2}\right]}=\Phi_{\mathrm{O}(D)} I_{254}\left[\mathrm{O}_{3}\right]
$$

where $I_{254}$ is the 254-nm illuminance and $\Phi_{\mathrm{O}(D)}=\phi_{3} \sigma_{3} /\left(k_{6}\left[\mathrm{~N}_{2}\right]+k_{7}\left[\mathrm{O}_{2}\right]\right)$ is a constant. This approximation is valid because $\mathrm{O}\left({ }^{1} D\right)$ is mostly produced by $\mathrm{R} 3$ and predominantly reacts via $\mathrm{R} 6$ and R7. If $\left[\mathrm{O}_{3}\right]$ and $I_{254}$ are known, $\left[\mathrm{O}\left({ }^{1} D\right)\right]$ can be analytically calculated using Eq. (3).

Similarly, for experimental conditions similar to ours, the densities of $\mathrm{O}$, $\mathrm{O}_{2}(a), \mathrm{O}_{2}(b), \mathrm{OH}$, and $\mathrm{HO}_{2}$ can be approximated as follows:

$$
\begin{aligned}
{[\mathrm{O}] } & \cong \frac{2 \sigma_{1} I_{185}\left[\mathrm{O}_{2}\right]+\sigma_{3} I_{254}\left[\mathrm{O}_{3}\right]}{k_{2}\left[\mathrm{O}_{2}\right]} \\
{\left[\mathrm{O}_{2}(a)\right] } & \cong \frac{\phi_{3} \sigma_{3} I_{254}}{k_{11}} \\
{\left[\mathrm{O}_{2}(b)\right] } & \cong \frac{0.8 k_{7}\left[\mathrm{O}_{2}\right]}{k_{15}\left[\mathrm{H}_{2} \mathrm{O}\right]} \Phi_{\mathrm{O}(D)} I_{254}\left[\mathrm{O}_{3}\right] \\
{[\mathrm{OH}] } & \cong \frac{2 k_{8} \Phi_{\mathrm{O}(D)}\left[\mathrm{H}_{2} \mathrm{O}\right] I_{254}+k_{29}\left[\mathrm{HO}_{2}\right]}{k_{20}\left[\mathrm{HO}_{2}\right] /\left[\mathrm{O}_{3}\right]+k_{27}} \\
{\left[\mathrm{HO}_{2}\right] } & \cong \frac{k_{27}[\mathrm{OH}]\left[\mathrm{O}_{3}\right]}{k_{20}[\mathrm{OH}]+k_{29}\left[\mathrm{O}_{3}\right]}
\end{aligned}
$$

where $I_{185}$ is the $185-\mathrm{nm}$ illuminance. $[\mathrm{OH}]$ and $\left[\mathrm{HO}_{2}\right]$ can be calculated by solving the simultaneous equations (7) and (8). Figure 5 shows the radical densities calculated using the numerical simulation with all reactions R1-R32 and those calculated using the analytical model of equations (3)-(8) with values of $\left[\mathrm{O}_{3}\right], I_{185}$, and $I_{254}$ obtained from the simulation. The difference between the analytical and full reaction models is within a factor of two. The analytical model gives a good approximation of the radical densities.

For the analytical model, the main production and reaction paths of the radicals can be discussed. For example, the main production and reaction paths of $\mathrm{O}_{2}(a)$ are $\mathrm{R} 3$ and $\mathrm{R} 11$, respectively, as shown in Eq. (5); i.e., $\mathrm{O}_{2}(a)$ is produced by ozone photodissociation (R3) and quenched by reaction with ozone (R11). Similarly, O atoms are mainly produced by the photodissociation of $\mathrm{O}_{2}$ and $\mathrm{O}_{3}(\mathrm{R} 1$ and $\mathrm{R} 3)$ and consumed by reaction with $\mathrm{O}_{2}(\mathrm{R} 2)$ to produce ozone. The $\mathrm{OH}$ radicals are mainly produced by $\mathrm{R} 8$ and the catalytic ozone destruction cycle (R29) and consumed by reaction with $\mathrm{HO}_{2}(\mathrm{R} 20)$ and 

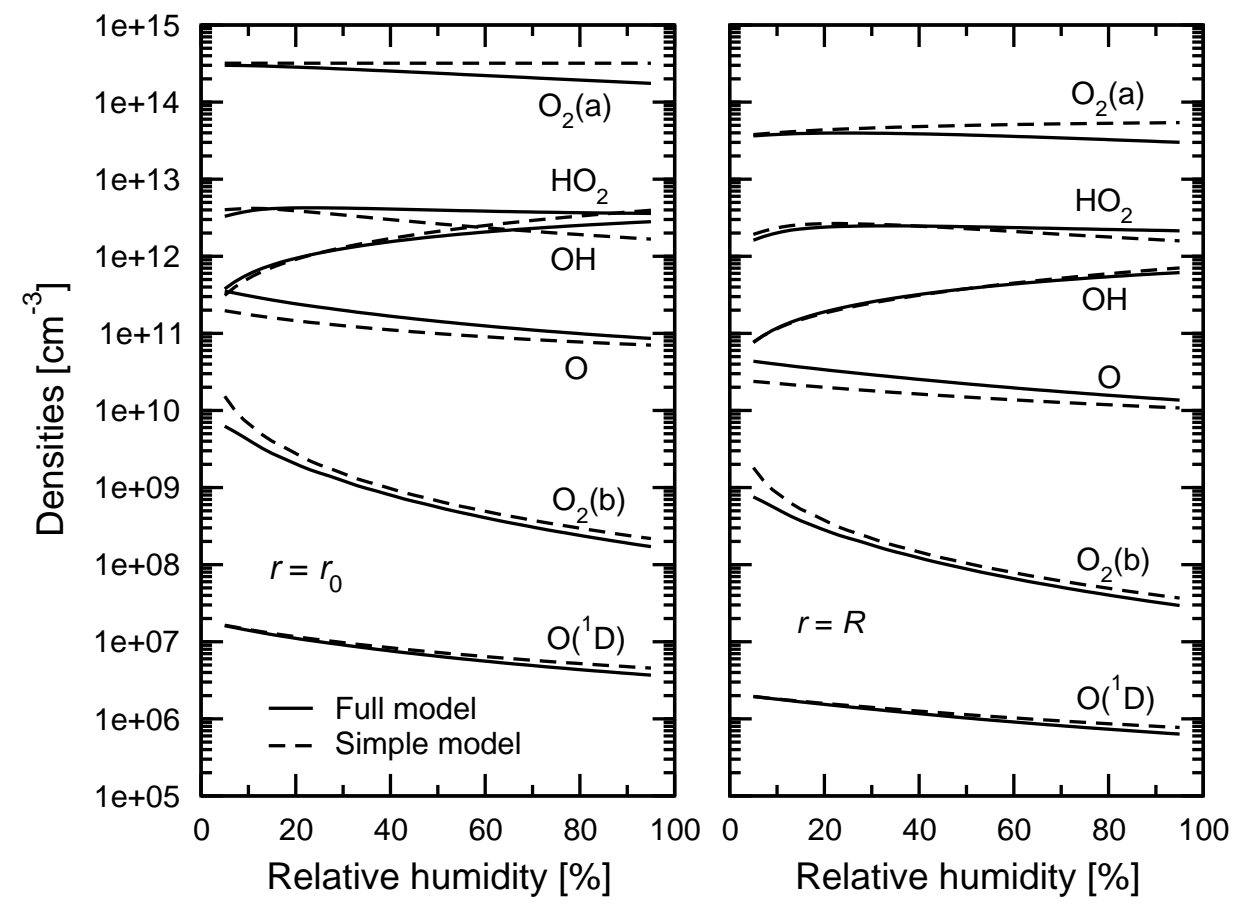

Figure 5: Radical densities calculated using the numerical simulation with all reactions and those calculated using the analytical model for different humidity conditions at $(r, z)=$ $(R, L / 2)$ and $\left(r_{0}, L / 2\right)$. Here $R=4 \mathrm{~cm}, T=25^{\circ} \mathrm{C}$, and $F=1.5 \mathrm{~L} / \mathrm{min}$. The numerical simulation used is model 2 .

the catalytic ozone destruction cycle (R27). $\mathrm{HO}_{2}$ is mainly produced by the catalytic ozone destruction cycle (R27) and consumed by reaction with $\mathrm{OH}$ (R20) and the catalytic ozone destruction cycle (R29). The radical densities are affected by humidity due to these reactions.

\section{Conclusions}

The effect of humidity on the densities of ozone and other radicals produced by a low-pressure mercury lamp was examined using a reaction model developed in the present work. After the reaction model was developed, the validity of the reaction model was verified by showing that the simulated ozone densities agreed well with the measured ones for different conditions. It was shown that there are three reasons for the decrease in the ozone density with increasing humidity: (i) decrease in $\mathrm{O}\left({ }^{3} \mathrm{P}\right)$ production (R1) due to 
attenuation of $185 \mathrm{~nm}$ radiation by $\mathrm{H}_{2} \mathrm{O}$ (R4); (ii) $\mathrm{O}_{3}$ destruction by $254 \mathrm{~nm}$ radiation arising from $\mathrm{R} 3$ and $\mathrm{R} 8$; and (iii) $\mathrm{O}_{3}$ destruction cycle by $\mathrm{OH}$ and $\mathrm{HO}_{2}$ (R27 and R29). The densities of $\mathrm{O}, \mathrm{O}\left({ }^{1} D\right), \mathrm{O}_{2}\left(a^{1} \Delta_{g}\right), \mathrm{O}_{2}\left(b^{1} \Sigma_{g}^{+}\right), \mathrm{OH}$, $\mathrm{HO}_{2}, \mathrm{H}$, and $\mathrm{H}_{2} \mathrm{O}_{2}$ were also calculated and the effect of humidity on those densities were discussed. Their main production and reaction paths were discussed based on the reaction model.

\section{Acknowledgments}

This work is partially supported by A-STEP of Japan Science and Technology Agency, and by the Grant-in-Aid for Science Research by the Ministry of Education, Culture, Sport, Science and Technology.

\section{References}

[1] J. P. Burrows, R. A. Cox, R. G. Derwent, Modulated photolysis of the ozone-water vapour system: Kinetics of the reaction of $\mathrm{OH}$ with $\mathrm{HO}_{2}$, J. Photochem. 16 (1981) 147-168.

[2] M. Salvermoser, D. E. Murnick, U. Kogelschatz, Influence of water vapor on photochemical ozone generation with efficient $172 \mathrm{~nm}$ xenon excimer lamps, Ozone Sci. Eng. 30 (2008) 228-237.

[3] K. Yoshihara, Y. Takatori, K. Miyazaki, Y. Kajii, Ultraviolet lightinduced water-droplet formation from wet ambient air, Proc. Jpn. Acad., Ser. B, 83 (2007) 320-325.

[4] Y. S. Shen, Y. Ku, Treatment of gas-phase volatile organic compounds (VOCs) by the UV/O 3 process, Chemosphere 38 (1999) 1855-1866.

[5] J. H. Wang, M. B. Ray, Application of ultraviolet photooxidation to remove organic pollutants in the gas phase, Sep. Pur. Technol. 19 (2000) $11-20$.

[6] S. Zen, D. Saito, R. Ono and T. Oda, Low-temperature sintered dyesensitized solar cell using surface treatment of $\mathrm{TiO}_{2}$ photoelectrode with ultraviolet light, Chem. Lett. to be published.

[7] J. R. Vig, UV/ozone cleaning of surfaces, J. Vac. Sci. Technol. A 3 (1985) 1027-1034. 
[8] L. F. Macmanus, M. J. Walzak, N. S. Mcintyre, Study of ultraviolet light and ozone surface modification of polypropylene, J. Polym. Sci. A 37 (1999) 2489-2501.

[9] J. C. Brock, R. T. Watson, Ozone photolysis: Determination of the $\mathrm{O}\left({ }^{3} \mathrm{P}\right)$ quantum yield at $266 \mathrm{~nm}$, Chem. Phys. Lett. 71 (1980) 371-375.

[10] R. Atkinson, D. L. Baulch, R. A. Cox, J. N. Crowley, R. F. Hampson, R. G. Hynes, M. E. Jenkin, M. J. Rossi, J. Troe, Evaluated kinetic and photochemical data for atmospheric chemistry: Volume I - gas phase reactions of $\mathrm{O}_{x}, \mathrm{HO}_{x}, \mathrm{NO}_{x}$ and $\mathrm{SO}_{x}$ species, Atmos. Chem. Phys. 4 (2004) 1461-1738.

[11] L. T. Molina, M. J. Molina, Absolute absorption cross sections of ozone in the 185- to 350-nm wavelength range, J. Geophys. Res. 91 (1986) 14501-14508.

[12] R. Atkinson, D. L. Baulch, R. A. Cox, R. F. Hampson Jr., J. A. Kerr, J. Troe, Evaluated kinetic and photochemical data for atmospheric chemistry supplement IV, J. Phys. Chem. Ref. Data 21 (1992) 1125-1568.

[13] D. S. Stafford and M. J. Kushner, $\mathrm{O}_{2}\left({ }^{1} \Delta\right)$ production in $\mathrm{He} / \mathrm{O}_{2}$ mixtures in flowing low pressure plasmas, J. Appl. Phys. 96 (2004) 2451-2465.

[14] J. A. Manion, R. E. Huie, R. D. Levin, D. R. Burgess Jr., V. L. Orkin, W. Tsang, W. S. McGivern, J. W. Hudgens, V. D. Knyazev, D. B. Atkinson, E. Chai, A. M. Tereza, C.-Y. Lin, T. C. Allison, W. G. Mallard, F. Westley, J. T. Herron, R. F. Hampson, and D. H. Frizzell, NIST Chemical Kinetics Database, NIST Standard Reference Database 17, Version 7.0 (Web Version), Release 1.4.3, Data version 2008.12, National Institute of Standards and Technology, Gaithersburg, Maryland, 20899-8320. Web address: http://kinetics.nist.gov/

[15] D. L. Baulch, C. T. Bowman, C. J. Cobos, R. A. Cox, Th. Just, J. A. Kerr, M. J. Pilling, D. Stocker, J. Troe, W. Tsang, R. W. Walker, J. Warnatz, Evaluated kinetic data for combustion modeling: supplement II, J. Phys. Chem. Ref. Data 34 (2005) 757-1397.

[16] D. J. Creasey, D. E. Heard, J. D. Lee, Absorption cross-section measurements of water vapour and oxygen at $185 \mathrm{~nm}$. Implications for the 
calibration of field instruments to measure $\mathrm{OH}, \mathrm{HO}_{2}$ and $\mathrm{RO}_{2}$ radicals, Geophys. Res. Lett. 27 (2000) 1651-1654.

[17] D. Kartal, M. D. Andrés-Hernández, L. Reichert, H. Schlager, J. P. Burrows, Technical note: Characterization of a DUALER instrument for the airborne measurement of peroxy radicals during AMMA 2006, Atmos. Chem. Phys. 10 (2010) 3047-3062.

[18] M. Tamura, P. A. Berg, J. E. Harrington, J. Luque, J. B. Jeffries, G. P. Smith, D. R. Crosley, Collisional quenching of $\mathrm{CH}(\mathrm{A}), \mathrm{OH}(\mathrm{A})$, and $\mathrm{NO}(\mathrm{A})$ in low pressure hydrocarbon flames, Combust. Flame 114 (1998) 502-514.

[19] R. Kienle, M. P. Lee, K. Kohse-Höinghaus, A detailed rate equation model for the simulation of energy transfer in OH laser-induced fluorescence, Appl. Phys. B 62 (1996) 583-599.

[20] U. Rahmann, W. Kreutner, K. Kohse-Höinghaus, Rate-equation modeling of single- and multiple-quantum vibrational energy transfer of $\mathrm{OH}\left(A^{2} \Sigma^{+}, v^{\prime}=0\right.$ to 3), Appl. Phys. B 69 (1999) 61-70.

[21] U. Rahmann, A. Bülter, U. Lenhard, R. Düsing, D. Markus, A. Brockhinke, K. Kohse-Höinghaus, LASKIN - A simulation program for timeresolved LIF-spectra, Internal Report, University of Bielefeld, Faculty of Chemistry, Physical Chemistry I, http://pc1.uni-bielefeld.de/ laskin. 